\title{
RANCANG BANGUN APLIKASI MONITORING DAN EVALUASI PENYALURAN DANA SOSIAL DI DINAS SOSIAL KABUPATEN SUMBAWA BERBASIS WEB
}

\author{
Teguh Hamdala ${ }^{1)}$, Shinta Esabella ${ }^{2)}$ \\ 1,2) Program Studi Teknik Informatika Universitas Teknologi Smbawa \\ Email :teguhhamdala@gmail.com ${ }^{1)}$ shinta.esabella@uts.ac.id ${ }^{2}$
}

\begin{abstract}
Abstraksi
Penelitian ini bertujuan untuk merancang dan membangun Aplikasi Monitoring dan Evaluasi (Monev) Penyaluran Dana Sosial di Dinas Sosial Kabupaten Sumbawa Berbasis Web agar dapat membantu Dinas Sosial di Bidang Fasilitasi Perlindungan dan Jaminan Sosial dalam melaporkan atau evaluasi terhadap kondisi dana sosial sekaligus juga melakukan proses monitoring perubahan penerima dana sosial di Kabupaten Sumbawa. Metode pengumpulan data yang digunakan dalam penelitian ini yaitu wawancara, observasi dan studi pustaka serta menggunakan Metode Spiral sebagai Metode Pengembangan Perangkat Lunak. Aplikasi ini dibangun menggunakan bahasa pemrograman Hypertext Propocessor (PHP) dan basis data MySQL sebagai Database Management Sistem (DBMS). Aplikasi ini dapat membantu Dinas Sosial di Bidang Fasilitasi Perlindungan dan Jaminan Sosial dalam melaporkan atau evaluasi terhadap kondisi dana sosial sekaligus juga melakukan proses monitoring perubahan penerima dana sosial di Kabupaten Sumbawa.
\end{abstract}

Kata Kunci :

Monev, Dana Sosial, Metode Spiral, Berbasis Web

\begin{abstract}
This study aims to design and build a Monitoring and Evaluation (Monev) Application for Distribution of Social Funds in the Web-Based Sumbawa Regency Social Service in order to assist the Social Service in the Field of Facilitation and Social Security Facilitation in reporting or evaluating the conditions of social funds as well as monitoring changes recipient of social funds in Sumbawa Regency. Data collection methods used in this study are interviews, observation and literature studies and using spiral methods as a method of software development. This application was built using the Hypertext Propocessor (PHP) programming language and MySQL database as a Database Management System (DBMS). This application can help the Social Service in the Field of Facilitation of Protection and Social Security in reporting or evaluating the conditions of social funds while also carrying out the process of monitoring changes in recipients of social funds in Sumbawa Regency.
\end{abstract}

Keywords :

Monev, Social Fund, Spiral Methode, Web Based

\section{Pendahuluan}

Pemerintah indonesia saat ini melakukan pembangunan dengan giat-giatnya di segala bidang, diantaranya pembangunan infrastruktur di seluruh wilayah indonesia dan peningkatan kompetensi sumber daya manusia di berbagai bidang, hal ini dilakukan untuk membentuk bangsa yang yang mampu bersaing di dunia internasional. Di wilayah indonesia sendiri memiliki karakteristik yang berbeda, yang mengakibatkan potensi masing-masing daerah juga berbeda. Pembangunan negara indonesia dilakukan dengan harapan menciptakan dan meningkatkan kesejahtraan seluruh rakyat indonesia. Peran pemerintah bukanlah satu-satunya yang bertanggung jawab dalam pembangunan, namun juga tanggung jawab bersama seluruh masyarakat indonesia. Dengan berpartisipasinya masyarakat dalam membangun Bangsa dan Negara, maka dapat dikatakan tatanan berbangsa yang ideal, demikian juga dengan Negara Republik Indonesia.

Dinas Sosial merupakan Lembaga Pemerintah yang bertugas menjalankan kegiatan di Bidang Sosial, Kepala Dinas yang memimpin Dinas Sosial ini bertanggung jawab kepada Bupati. Dinas Sosial Kabupaten Sumbawa melaksanakan beberapa tugas umum Pemerintah dan melakukan pembangunan di Bidang Kesejahtraan Sosial.

Pada Dinas Sosial Kabupaten Sumbawa telah memiliki (SIKSNG) Sistem Informasi Kesejahtraan Sosial Next Generation, di mana sistem tersebut dari tingkat pusat yang memiliki data dan informasi di seluruh Indonesia. Data yang ada di Sumbawa masih 
mengikuti atau sebagai user dari SIKSNG ini, seperti Kepala Bidang yang mengelolah data Kesejahtraan Sosial tersebut jika ingin melakukan monitoring atau ingin melaporkan kepada Bupati masih harus memasukkan data ke Microsoft Excel setelah itu baru dilakukan sorting secara manual, dan ini membutuhkan waktu yang lama sehingga dirasa kurang efektif dan efisien oleh Kepala Bidang Fasilitasi Perlindungan dan Jaminan Sosial. Seperti yang disampaikan oleh Bapak Mirajudin, ST dalam proses wawancara yang peneliti lakukan, beliau menyampaikan : "Untuk mendukung penyaluran dana sosial di Dinas Sosial Kabupaten Sumbawa dibutuhkan adanya aplikasi lokal yang melingkupi data dari SIKSNG sehingga mudah pelaporannya di tingkat daerah"[1].

Berdasarkan permasalahan di atas peneliti mencoba membangun Aplikasi Monitoring dan Evaluasi Penyaluran Dana Sosial di Dinas Sosial Kabupaten Sumbawa Berbasis Web, dimana aplikasi ini memasukkan data yang berasal dari SIKSNG. Kemudian peneliti melakukan query terhadap data yang sering dilaporkan kepada Pimpinan Daerah. Dimana data yang dilaporan secara rinci sesuai dengan permintaan data yang ingin ditampilkan dan dilaporkan menggunakan query pemrograman MYSQL, sehingga pelaporan yang diinginkan oleh Pimpinan Daerah mudah berdasarkan data jumlah warga yang miskin atau warga yang menerima dana sosial dengan memanfaatkan query di MYSQL server, selain itu aplikasi ini juga bisa mendukung untuk memperbarui data di mana data yang dimasukkan adalah data yang biasa dilaporkan di SIKSNG yaitu meliputi data monitoring perkembangan kondisi penerima dana sosial.

Harapannya dengan aplikasi yang dibangun dapat membantu Dinas Sosial di Bidang Fasilitasi Perlindungan dan Jaminan Sosial dalam melaporkan atau evaluasi terhadap kondisi dana sosial sekaligus juga memonitoring perubahan penerima dana sosial di Kabupaten Sumbawa.

\section{Tinjauan Pustaka}

Penelitian pertama yang menjadi bahan acuan ialah penelitian yang dilakukan oleh Khairul Anwar, Bakir, dan Khoiriyah [2]. Dalam penelitian tersebut memiliki tujuan untuk membantu dalam memonitor setiap kas masuk dana dan kas keluar dana yang dilakukan masing-masing Desa di Kecamatan Kadur - Sistem ini menggunakan media website untuk mempermudah koordinasi desa dan Kecamatan. Sehingga diharapkan dengan adanya sistem ini dapat lebih mempercepat proses pemantauan dan pelaporan kegiatan Desa di Kecamatan Kadur.

Selanjutnya yaitu penelitian yang dilakukan oleh Rayadi [3] mahasiswa dan alumni Akademi Manajemen Informatika Panca Bhakti Pontianak. Dengan judul penelitian "Analisis Sistem Penyaluran Bantuan Ke Desa Pada Lingkungan Kabupaten Di Provinsi Kalimantan Barat". Tujuan dari penelitian ini adalah untuk mengetahui sistem penyaluran bantuan ke desa pada lingkungan Kabupaten di Kalimantan Barat.

Penelitian terakhir yang menjadi literatur dalam penelitian ini yaitu ditulis oleh Putri Azizah Helena mahasiswa dan alumni Universitas Islam Negeri Syarif Hidayatullah Jakarta [4]. Dengan judul penelitian "Efektifitas Penyaluran Dana Sosial". Tujuan dari penelitian ini adalah Sebagai tambahan literatur terutama yang berkaitan dengan masalah penyaluran dana sosial. Sebagai kontribusi pemikiran bagi Bank Syariah Mandiri khususnya dan sebagai kontribusi pemikiran bagi lembaga penghimpun dan penyalur dana sosial lainnya.

Dari penelitian yang telah dilakukan seperti diatas, penulis juga melakukan penelitian tentang Rancang Bangun Aplikasi Monitoring dan Evaluasi Penyaluran Dana Sosial di Dinas Sosial Kabupaten Sumbawa Berbasis Web yang tujuannya adalah dapat membantu Dinas Sosial di Bidang Fasilitasi Perlindungan dan Jaminan Sosial dalam melaporkan atau evaluasi terhadap kondisi dana sosial sekaligus juga memonitoring perubahan penerima dana sosial di Kabupaten Sumbawa.

2.1 Monitoring adalah penilaian yang terus menerus terhadap fungsi kegiatan-kegiatan proyek didalam konteks jadwal-jadwal pelaksanaan dan terhadap penggunaan input-input proyek oleh kelompok didalam kontek harapan-harapan rancangan.

2.2 Evaluasi adalah penilaian berkala terhadap relevansi,penilaian, efisiensi dan dampak proyek tentang waktu, daerah atau populasi.

2.3 Penyaluran Dana Sosial, Penyaluran menurut Kamus Besar Bahasa Indonesia, berasal dari kata salur yang berarti mengalirkan, mengarahkan,meneruskan atau mendistribusikan, penyaluran sendiri dapat dipahami sebagai proses, cara, ataupun perbuatan menyalurkan.

2.4 Aplikasi adalah penggunaan atau penerapan suatu konsep yang menjadi pokok pembahasan. Aplikasi dapat diartikan juga sebagai program komputer yang dibuat untuk menolong manusia dalam melaksanakan tugas tertentu [5].

\section{Metode Penelitian}

Metode yang digunakan dalam penelitian ini adalah penelitian deskriptif kualitatif yang dimana menurut Moleong [6] deskriptif kualitatif artinya mencatat dengan teliti berbagai fenomena yang dilihat dan didengar serta dibaca via wawancara atau catatan lapangan, foto, video tape, dokumentasi pribadi, catatan serta memo dan lain-lain. Peneliti harus membanding- bandingkan, mengkombinasikan, mengabstraksikan dan menarik kesimpulan. Dalam penelitian deskriptif kualitatif jenis data yang dikumpulkan berupa kata-kata, gambar dan bukan angka-angka.Hal ini dikarenakan berbagai data yang terkumpul kemungkinan menjadi kunci terhadap apa yang akan atau sudah diteliț 
Adapun metode yang digunakan dalam adalah sebagai berikut:

1. Metode Pengumulan Data

Metode pengumpulan data merupakan metode yang digunakan untuk mengumpulkan data yang diperlukan, adapun metodenya sebagai berikut :

a. Wawancara

Wawacara dilakukan untuk mengumpulkan data secara langsung dengan cara melakukan tanya jawab dengan pihak Dinas Sosial.

b. Observasi

Observasi dilakukan dengan cara terjun langsung ke lokasi untuk mendapatkan datadata yang diperlukan dalam penelitian ini.

c. Studi pustaka

Studi pustaka dilakukan dengan cara mengumpulkan data- data atau informasi diinternet, jurnal dan skripsi yang berkaitan dengan penelitian ini.

2. Metode Pegembaga Peragkat Luak

Metode pengembangan perangkat lunak yang digunakan dalam penelitian ini adalah Metode Spiral, karena model proses pengembangan perangkat lunak spiral merupakan model proses pengembangan perangkat lunak evolusioner yang menggabungkan pendekatan prototyping yang bersifat iterative dengan aspek-aspek sistematis dan terkendali seperti yang kita jumpai pada model air terjun (waterfall) [7]. Berikut ini adalah model pengembangan spiral :

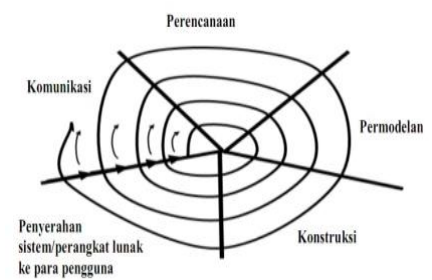

Gambar 1. Spiral Models

Berikut ini tahapan-tahapan dalam pengembangan perangkat lunak menggunakan Spiral Models:

a. Komunikasi

Pada tahap ini dilakukan komunikasi dengan pihak Dinas Sosial mengenai data-data atau informasi yang dibutuhkan dalam aplikasi yang akan dibuat.

b.Perencanaan

Pada tahap ini dilakukan perencanaan penjadwalan pembuatan aplikasi dan menganalisa masalah- masalah yang akan muncul pada saat pemakaian aplikasi, serta menganalisa data-data atau infomasi yang ada.

c. Permodelan
Pada tahap ini dilakukan proses analisa bagaimana gambaran dari aplikasi yang akan dibuat.

d. Konstruksi

Pada tahap ini dilakukan proses penterjemahan bentuk disain menjadi kode, yang dimana bentuk bahasa yang dapat dibaca dan dikenali oleh mesin kemudian setelah pengkodean selesai, maka dilakukan pengujian pada aplikasi dan juga kode yang dibuat. Tujuannya untuk menemukan kesalahan yang mungkin terjadi untuk nantinya diperbaiki.

e. Penyerahan sistem atau perangkat lunak ke para pengguna atau pelanggan

Pada tahap ini merupakan tahap terakhir yang dilakukan oleh peneliti, yakni penyerahan aplikasi kepada pihak Dinas Sosial.

\section{Hasil dan Pembahasan}

\section{Metode Pengembangan Sistem}

dalam membangun aplikasi monitoring dan evaluasi penyaluran dana sosial di Dinas Sosial Kabupaten Dalam merancang Sumbawa berbasis web peneliti melakukan menggunakan metode spiral dengan 5 langkah tersebut:

\section{A. Komunikasi}

Tahapan ini merupakan hasil dari wawancara dan observasi dilakukan berikut hasil sebagai berikut:

a. Hasil Wawancara

Pada saat peneliti melakukan wawanca dengan bapak Mirajudin, ST selaku ketua Bidang Fasilitasi Perlindungan Dan Jaminas Sosial Di Dinas Sosial Kabupaten Sumbawa beliau menyampaikan "Untuk mendukung penyaluran dana sosial di Dinas Sosial Kabupaten Sumbawa dibutuhkan adanya aplikasi lokal yang melingkupi data dari SIKSNG sehingga mudah pelaporannya di tingkat daerah".

b. Hasil Observasi

Peneliti langsung pergi ke Dinas Sosial Kabupaten Sumbawa untuk mendapatkan data yang dibutuhkan oleh aplikasi, data yang dibutuhkan berupa data Microsoft excel Basis Data Terpadu Anggaran Rumah Tangga (BDT ART).

c. HasilStudi Pustaka

Peneliti mencari data dan informasi di internet, jurnal dan skripsi, data dan informasi yang dicari berupa teori-teori di bab 2 yang berhubungan dengan penelitian yang peneliti kerjakan.

\section{B. Perencanaan}

Tahapan kedua, peneliti membuat jadwal pengerjaan project selama 5 bulan dari bulan Februari sampai bulan Juli 2019. 
C. Pemodelan

Pada pemodelan ini melakukan tiga perancangan yaitu, rancangan sistem, perancangan database dan rancangan tampilan, sebagai berikut:

1. Rancangan Sistem

Adapun rancangan sistem dari aplikasi monitoring dan evaluasi penyaluran dana sosial di Dinas Sosial Kabupaten Sumbawa sebagai berikut :

a. Sistem Yang Sedang Berjalan

Berdasarkan hasil wawancara yang dilakukan peneliti di Dinas Sosial Kabupaten Sumbawa diketahui sistem yang sedang berjalan saat ini terlihat pada Flowmap sebagai berikut :

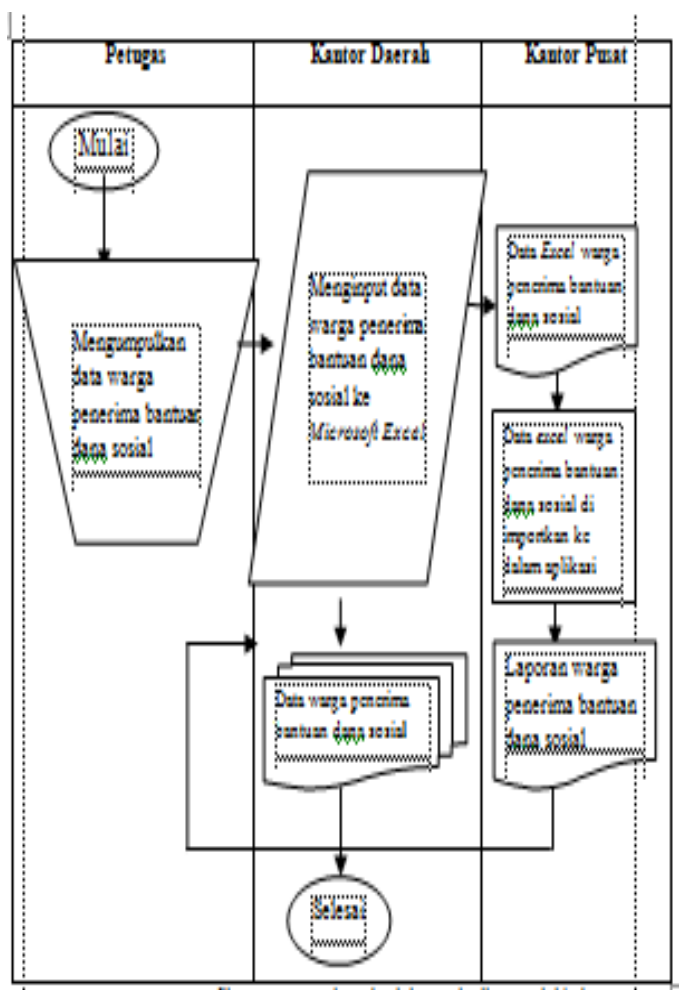

Gambar 2. Flowmap Sistem Berjalan

Sistem yang sedang berjalan pada Dinas Sosial Kabupaten Sumbawa dalam proses monitoring dan evaluasi penyaluran dana sosial dirasa kurang efektif dan efisien karena jika ingin melakukan monitoring atau ingin melaporkan kepada Bupati masih harus memasukkan data ke Microsoft Excel setelah itu baru dilakukan sorting secara manual.

b. Sistem Yang Diusulkan

Berdasarkan masalah-masalah yang telah dijelaskan sebelumnya, penulis bermaksud mengusulkan pembuatan aplikasi monitoring dan evaluasi penyaluran dana sosial di Dinas Sosial Kabupaten Sumbawa berbasis web yang nantinya dapat memudahkan dalam memonitoring dan mengevaluasi penyaluran dana sosial di
Dinas Sosial Kabupaten Sumbawa, adapun gambaran sistem monitoring dan evaluasi penyaluran dana sosial di Dinas Sosial Kabupaten Sumbawa adalah sebagai berikut

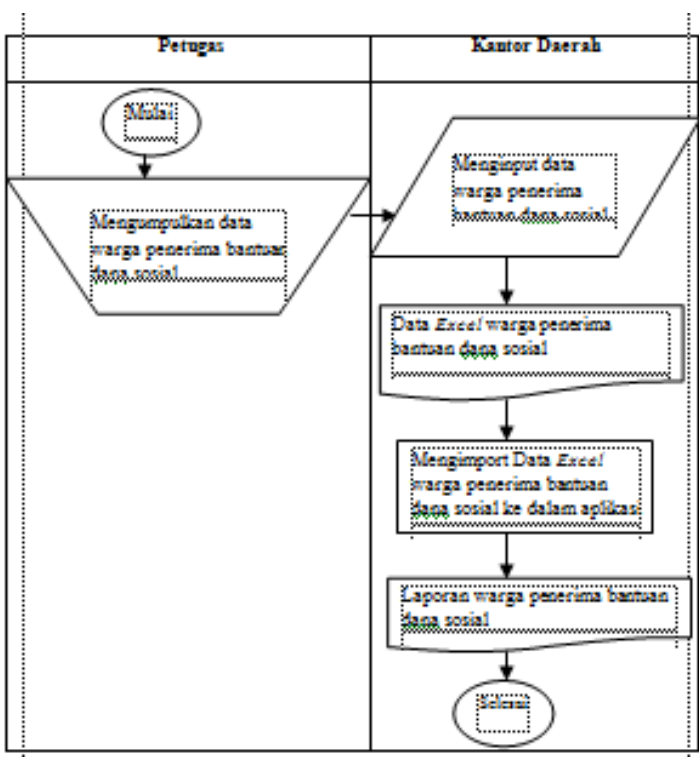

Gambar 3. Flowmap Sistem Usulan

c. Sistem Yang Diusulkan

Diagram Kontek

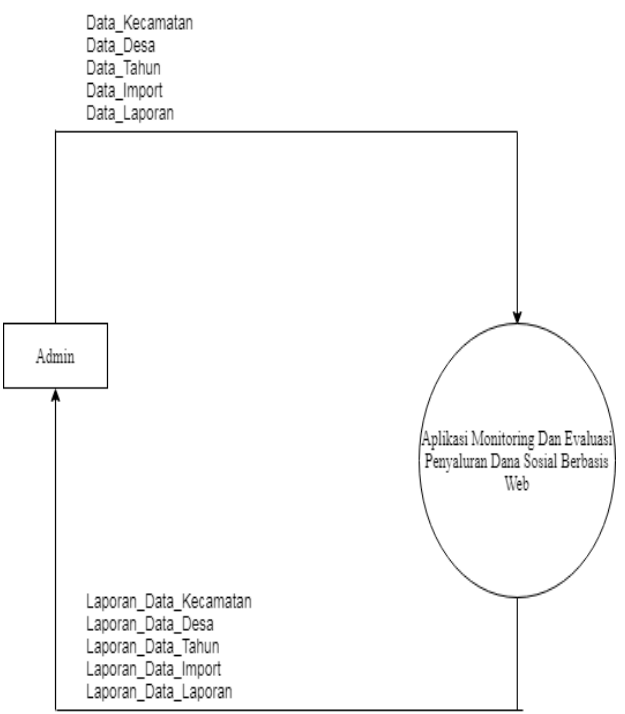

Gambar 4. Diagram Konteks

Gambar diagram konteks di atas merupakan gambaran umum dari organisasi sistem yang akan dibangun.

\section{Data Flow Diagram (DFD)}

Berdasarkan diagram konteks, Aplikasi Monitoring Dan Evaluasi Penyaluran Dana Sosial di Dinas Sosial Kabupaten Sumbawa Berbasis Web terdiri dari tiga aktivitas utam 
yaitu : (Master Data, Import dan Laporan) Aktivitas secara keseluruhan beserta aliran datanya ditunjukan pada gambar berikut:

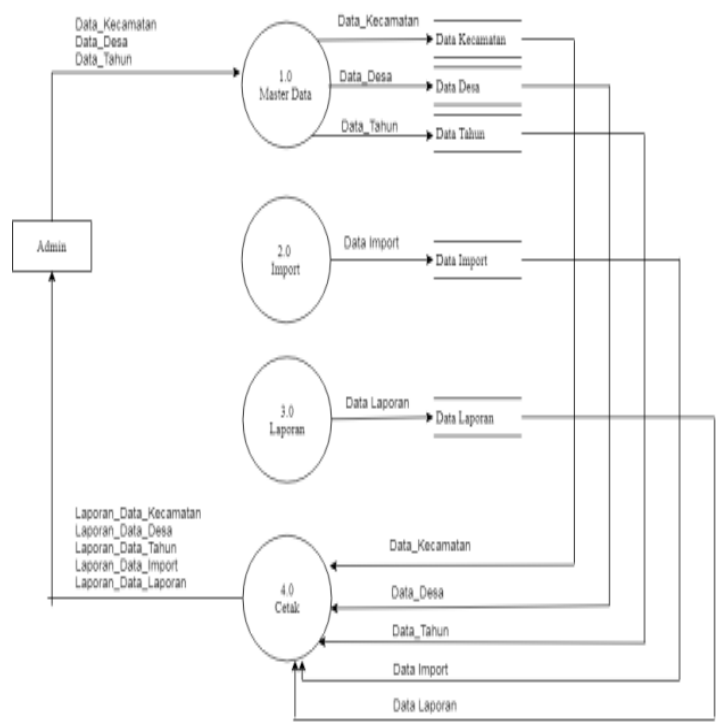

Gambar 5. Data Flow Diagram Level

\section{Rancangan Database}

Berikut adalah Entity Relationship Diagram [8] yang terdapat dalam Aplikasi Monitoring Dan Evaluasi Penyaluran Dana Sosial di Dinas Sosial Kabupaten Sumbawa Berbasis Web :

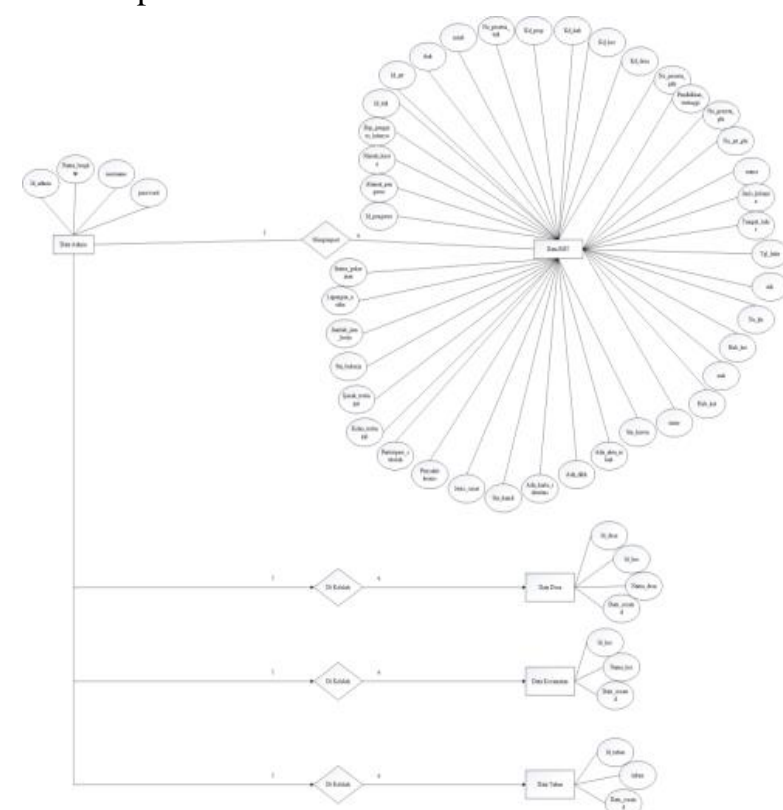

Gambar 6. Eentity Relationship Diagram

\section{Relasi Antar Tabel}

Setelah merancang seluruh objek - objek pada aplikasi monitoring dan evaluasi penyaluran dana sosial di Dinas Sosial Kabupaten Sumbawa berbasis web, penulis melakukan pemetaan skema database untuk menentukan relasi hubungan primary-key dan foreign-key dari antar tabel sebagai berikut :

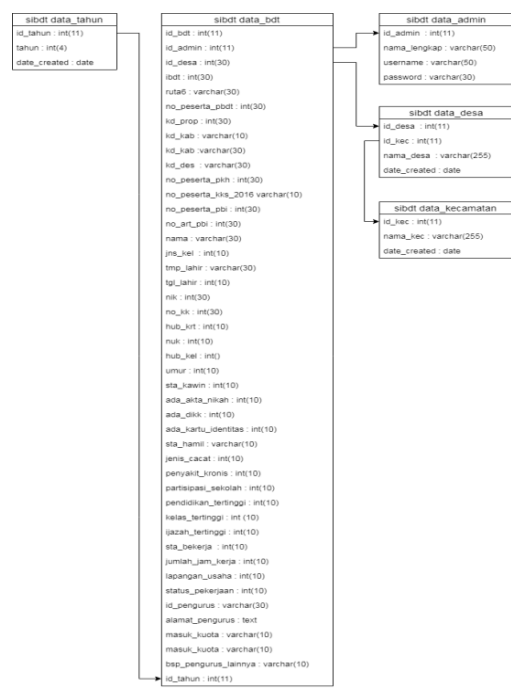

Gambar 7. Relasi Antar Tabel

\section{Rancangan Interface}

Adapun rancangan interface dariAplikasi Monitoring Dan Evaluasi Penyaluran Dana Sosial di Dinas Sosial Kabupaten Sumbawa Berbasis Web sebagai berikut :

a. Rancangan Halaman Login

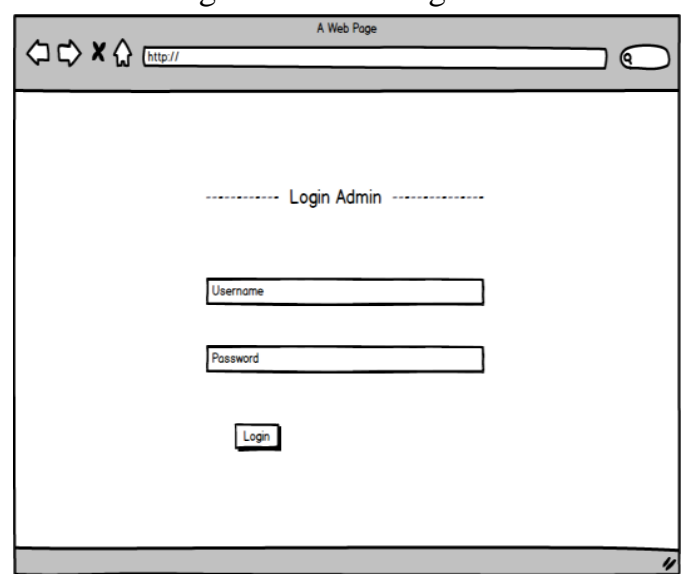

Gambar 8. Rancangan Halaman Login

Tampilan di atas merupakan tampilan halaman login yang berisikan username dan password yang kemudian admin melakukan Login untuk masuk ke Halaman Utama.

b. Rancangan Halaman Utama 


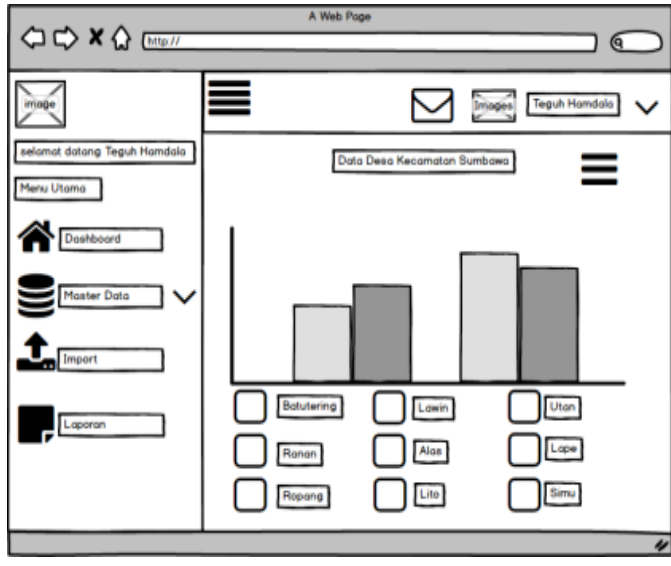

Gambar 9. Rancangan Halaman Utama

Di halaman ini terdapat beberapa menu yaitu menu Dashboard Master Data, Import dan menu Laporan.

\section{Kontruksi}

Adapun pembuatan aplikasi ini dibagun menggunkan sublime text dengan bahasa PHP.

\section{Tampilan Halaman Login}

Adapun tampilan Halaman Login pada Aplikasi Monitoring Dan Evaluasi Penyaluran Dana Sosial di Dinas Sosial Kabupaten Sumbawa Berbasis Web sebagai berikut :

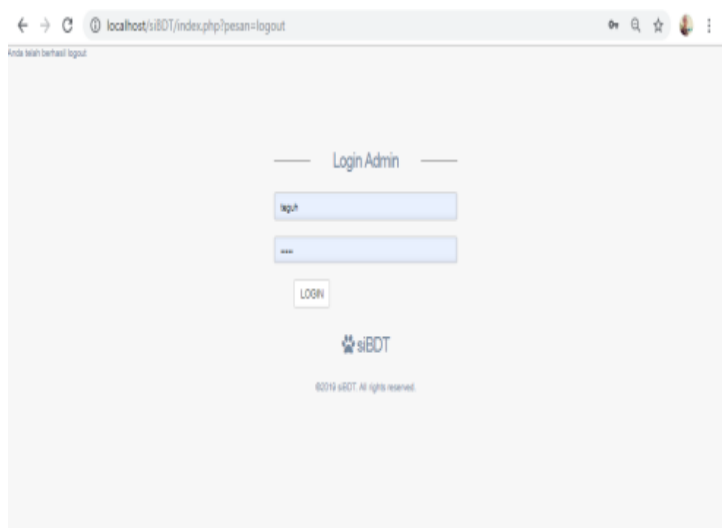

Gambar 10. Tampilan Halaman Login

Pada gambar di atas menunjukkan tampilan halaman login yang berisikan username dan password yang kemudian Login untuk masuk ke Halaman Utama.

\section{Tampilan Dashboard}

Adapun tampilan Halaman dasboard pada Aplikasi Monitoring Dan Evaluasi Penyaluran Dana Sosial di Dinas Sosial Kabupaten Sumbawa Berbasis Web sebagai berikut :

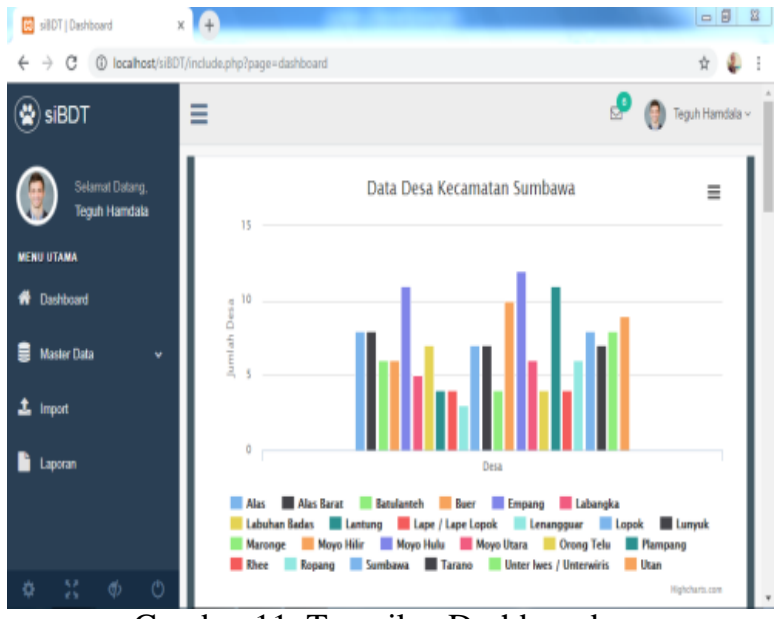

Gambar 11. Tampilan Dashboard

Pada gambar di atas terdapat beberapa menu yaitu menu Dashboard Master Data, Import dan menu Laporan.

\section{Pengujian Aplikasi}

Berikut ini adalah pengujian Aplikasi Monitoring Dan Evaluasi Penyaluran Dana Sosial Di Dinas Sosial Kabupaten Sumbawa Berbasis Web dilakukan menggunakan pengujian black box yaitu pengujian pada sistem admin.

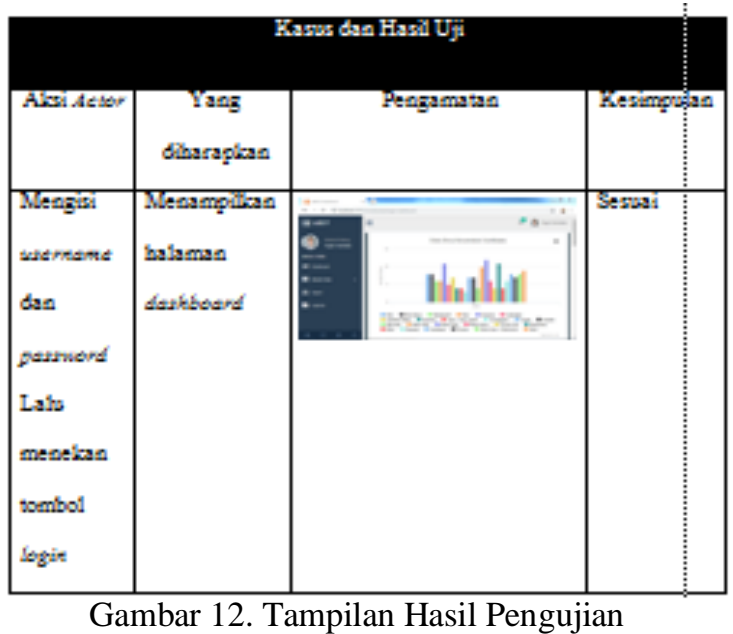

E. Penyerahan sistem atau perangkat lunak ke para pengguna atau pelanggan

Setelah peneliti menyelesaikan tahapan-tahapan penelitian. Maka, selanjutnya peneliti menyerahkan hasil penelitian kepada pihak terkait yaitu Dinas Sosial Kabupaten Sumbawa.

\section{Kesimpulan}

Aplikasi telah berhasil dibangun menggunakan bahasa pemrograman Hypertext Propocessor (PHP) dan basis data MySQL sebagai Database Management Sistem (DBMS). Aplikasi ini menjadi masukkan bagi Dinas Sosial Kabupaten Sumbawa dalam Bidang Fasilitasi Perlindungan dan Jaminan Sosial dalam melaporkan atau evaluasi terhadap 
kondisi dana sosial sekaligus juga melakukan proses monitoring perubahan penerima dana sosial di Kabupaten Sumbawa.

\section{Daftar Pustaka}

[1] Mirajuddin. 2019. Wawancara Dinas Sosial Kabupaten Sumbawa.

[2] Khairul A, Bakir, Khoiriyah. 2017 "Perancang Sistem Informasi Monitoring Dana Desa Berbasis Web (Studi Kasus: Desa Sekecamatan Kadur)". Seminar Nasional Humaniora \& Aplikasi Sistem Informasi pp. 139.

[3] Rayadi. 2016 "Analisis Sistem Penyaluran Bantuan Ke Desa Pada Lingkungan Kabupaten Di Provinsi Kalimantan Barat". Jurnal Eksos 11(1) pp. 85.

[4] Putri Azizah H. 2017 "Efektifitas Penyaluran Dana Sosial". Skripsi Program Studi Ekonomi Syariah, Universitas Islam Negeri Syarif Hidayatullah Jakarta.

[5] Sandro S. 2013 "Perancangan Aplikasi Steganografi Untuk menyisipkan Pesan Text Pada Gambar Dengan Metode End of File". Jurnal Pelita Informatika Budi Darma 4(2) pp.46.

[6] Lexy Moleong. 2016. Metodologi penelitian kualitatif. Bandung : PT Remaja Rosda Karya.

[7] Pressman. 2015. Rekayasa Perangkat Lunak: Pendekatan Praktisi Buku I. Yogyakarta: Andi.

[8] Rita A, Shinta E, Yudi M. 2017 Membangun Sistem Inventory Data Barang (Studi Kasus : Apotek An-Nafi Sumbawa). Jurnal Tambora 2(2) pp. 95 . 